\title{
Social Integration and Proactive Attitudes Towards the Integration of Immigrants in a Sample of the Swedish-Speaking Minority of Western Finland
}

\author{
Ingrida Grigaitytè (Corresponding author) \\ Developmental Psychology, Åbo Akademi University, Strandgatan 2, 65100, Vasa, Finland \\ E-mail: ingrida.grigaityte@abo.fi
}

\section{Karin Österman}

Developmental Psychology, Åbo Akademi University, Strandgatan 2, 65100, Vasa, Finland

\author{
Kaj Björkqvist
}

Developmental Psychology, Åbo Akademi University, Strandgatan 2, 65100, Vasa, Finland

Received: December 28, 2020

doi:10.5296/ijssr.v9i1.18122
Accepted: February 1, 2021 Published: March 11, 2021

URL: https://doi.org/10.5296/ijssr.v9i1.18122

\begin{abstract}
The relationship between respondents' personal level of social integration and their proactive attitudes towards the integration of immigrants was investigated in a sample of the Swedish-speaking minority of Western Finland. A questionnaire was completed by 298 respondents (208 females, 90 males, $M_{\text {age }}=31.6, S D=13.5$ ), consisting of one scale measuring social integration and three scales measuring proactive attitudes. Respondents having high scores on social integration scored significantly higher on recognizing the need of making cultural efforts to support immigrants, making structural efforts in society for the same, and openness to diversity than those with lower scores on social integration. The most prominent difference between the groups was in the case of openness to diversity. Thus, a clear relationship between one's personal level of social integration and having proactive attitudes towards the integration of immigrants was found.
\end{abstract}

Keywords: social integration, proactive attitudes, integration of immigrants, Finland, Swedish-speakers 


\section{Introduction}

During the past decades, Finland has had rather strict rules and tough requirements about immigration policy and legislation on family reunification (Tapaninen, Halme-Tuomisaari, \& Kankaanpää, 2019). Nevertheless, Finland has been a desirable destination for immigrants looking for higher quality living standards, including safety, economic stability, social security, education, and employment. As a consequence of that and in light of the increasing globalization and the ongoing refugee situation in the world, Finland can be expected to become more ethnically diverse in the future (Valtioneuvosto, 2015).

Until the 1990s, Finland was an ethnically relatively homogenous country with only few immigrants. However, besides the Finnish-speaking natives, Finland also has a Swedish-speaking minority living mostly in the coastal areas. The existence of the Swedish-speaking population in Finland is historically interconnected with the 600-year long period of time when Finland was a part of Sweden, starting from around 1200 and ending with the Russian conquest of Finland in 1809 (Engman, 1995; Törnblom, 1993). In 1917, Finland received its independence. The constitution of the country states that it is bilingual with both Finnish and Swedish as official languages, and the Swedish-speakers have their own schools and higher-level education where the language of teaching is Swedish. The Swedish-speaking minority, the Finland-Swedes, can be regarded as relatively well-integrated in the Finnish society. It is therefore of interest to investigate how a well-integrated minority relates to present-day immigrant groups in the country. There is evidence to suggest that in order to receive and secure the acceptance of the majority group, minorities are more likely than the majority group to reject other minorities, to signal that they themselves belong to a different ethnic minority (Hindriks, Coenders, \& Verkuyten, 2005). This fact may be true in cases when both minorities are relatively new in a country, are not so well integrated, and experience their identity threatened. However, Swedish-speakers in Finland have more positive attitudes towards refugees and asylum-seekers than Finnish-speakers have (Pitkänen $\&$ Westinen, 2018). This circumstance may be due to the fact that the Swedish-speakers in Finland are a relatively well-integrated minority who do not experience their existence and culture threatened by newcomers in the country. Rather, they may feel empathy towards incoming minorities and relate more positively towards them than the majority does.

The level of one's own integration may thus be related to the proactive attitudes towards immigration. Accordingly, the current article investigates the relationship between the level of social integration of the Swedish-speaking population in the Ostrobothnia region of Western Finland and their proactive attitudes towards the integration of immigrants. Proactive attitudes towards immigrants are, in the context of the current study, operationalized by the recognition of the need for making cultural and structural efforts in support of immigration, and openness to diversity.

\subsection{Social Integration}

The concept of integration has a wide range of definitions, dependent on international, national as well as local contexts. Broadly, integration is defined by the process by which people who are relatively new to a hosting country become a part of the society. In the past 
decade, more complex and multidimensional models of integration have been suggested and implemented in various places among diverse populations. The current understanding of integration goes beyond assimilation to the pre-existing social order, and places instead more focus on inclusion, participation, cohesion, equality, multiculturalism, and health, during the process of resettlement (Robila, 2018).

Being a multifaceted phenomenon, social integration is a dynamic and structured process in which all members of the society in question participate, in order to maintain positive human social relationships. Esser $(1980,2006)$ distinguishes between four domains of integration: the structural, cultural, and social domains, and the emotional processes regarding identity formation and belonging. Berry (2011) writes that integration takes place when a minority group has an interest in maintaining their own culture while participating as an integral part of a host society. The aim is to bring together different ethnic groups without them losing their identities, and to give them access to all areas of community life (Berry, 2011; Ratts \& Pedersen, 2014). Strang and Ager (2010) describe integration as a two-way, long-term, and open-ended process, the success of which depends on how resourceful an individual is and how open the society is. The success of social integration may be assessed through such domains as rights and citizenship, language and cultural knowledge, safety and stability, social bridges, bonds and links, employment, housing, education, and health (Ager \& Strang, 2008). Thus, the level of integration depends on the extent, quality, and frequency of informal social relationships (e.g., having a spouse or other relatives from the community) or formal (e.g., engagement with religious institutions and voluntary organizations) (Brissette, Cohen, \& Seeman, 2000; Umberson \& Montez, 2010).

\subsection{The Integration of Immigrants in a Finnish Context}

Finland has been on the receiving end of immigration for some decades, with an increase since 1990. Nevertheless, the population of Finland is considered more ethnically homogenous in comparison with most European nations. Thus, historically, Finland has been a country of emigration rather than immigration. Until the end of the 1980s, returning migrants and their families (mostly from Sweden) accounted for some $85 \%$ of the immigrants arriving in Finland (OECD, 2018). In 2019, from the total population of 5,525,292, the number of people with foreign background was 423,494 (Statistics Finland, 2019). This number was affected by the European migrant crisis, bringing an inflow that the country had not experienced since World War II (Sarvimäki, 2017).

By the end of 2019, there were 19,047 foreign-language speakers living in the region of Ostrobothnia in Western Finland. The largest group was young adults whose age ranged from 25 to 39. The most common foreign languages spoken in the region were Vietnamese, Arabic, Russian, Bosnian, English, Somali, Estonian, Chinese, Ukrainian, Hungarian, Polish, Thai, Turkish, Romanian, and Persian. Explanations for the diversity of the immigrant population in Western Finland include the opportunities of higher education, the existence of large international enterprises, and the reception of refugees and immigrants (Ojala, 2020).

Finland's foreign population come from a diverse range of countries and, therefore, bringing with them a diverse range of integration services required. These include both immediate 
services regarding housing and initial settlement, and long-term challenges such as integration in the Finnish labor market and society. Prior to the 1990s, the Finnish integration policy was underdeveloped and was largely similar for the foreign as well as the native population. Since 1999, the Act on the Integration of Immigrants and Reception of Asylum Seekers brought forward policy instruments that mainly focused on individualized integration plans. These plans comprised a sequence of language courses, preparatory or vocational training, career counselling, and work experience (National Legislative Bodies, 1999; OECD, 2018). In 2011, the current law on integration, the Act on the Promotion of Immigrant Integration, came to force. Efforts were made to streamline the integration services with an objective to ensure that all immigrants are provided with the basic information about Finnish society, work life, and available integration services. Since then, the Finnish government has been striving to find ways in which the integration system could be more flexible, efficient, and cost effective (Integration, 2020; OECD, 2018).

The increase in the inflow of immigrants since 2015 was challenging for the Finnish integration system, which was designed to support far fewer refugees than actually have arrived. In 2016, the Finnish government published an action plan on integration that emphasized the economic potential of welcoming immigrants into the country. It has also strived to raise awareness of the potential role of labor migration in boosting employment, strengthening public finances, improving the dependency ratio, as well as increasing the links between the Finnish and the global economy (Ministry of Economic Affairs and Employment of Finland, 2016). Furthermore, Finland has launched the Talent Boost program aiming to attract more international talents while, simultaneously, channeling the expertise of international talent already residing in Finland. Despite the open migrant policies, attractiveness also depends on the capacity to recognize and reward. Some immigrants have been struggling to integrate and are quite distant from the labor force. In contrast to the 2016 action plan, some native Finns still perceive the integration of immigrants as a costly duty rather than as an opportunity. Thus, the specific way immigrants experience opportunities offered by the Finnish labor market are quite varying and do not match the data derived from the traditional talent attractiveness indices (OECD, 2018).

\subsection{The Integration of the Swedish-Speaking Minority of Western Finland}

The Swedish-speaking population in Finland has a long history. According to disputed evidence, Swedish speakers may have lived in the area that today constitutes Finland already in pre-historic times (McRae, Helander, \& Luoma, 1999; Saxén, 1905). It is historically established that the Swedish-speaking population started to settle in Finland at least as early as in the 12th or 13th century, mainly in the Western and Southern coastal areas. Until today, they symbolically identify themselves with the coast and the sea (Allardt \& Starck, 1981; Haggren et al., 2015; Tarkiainen, 2008).

In 1809, Russia conquered Finland from Sweden. During the years of Russian rule, a national awakening took place, leading to the birth process of Finland as a nation and its independence in 1917. This fact drastically altered the Swedish-speakers' position from having been a majority in their country to becoming a minority in a new country (Engman, 1995). 
The Swedish-speaking population in Finland, compared to other linguistic minorities in Western Europe, has achieved a solid position in society. The Swedish language was given an equal status in the 1922 constitution, and conscious efforts to keep Swedish as an administrative and educational language are being made until today (Andersson \& Herberts, 1996). The Finland-Swedes meet the major criteria of ethnicity: self-identification of ethnicity, language, social structure, and ancestry (Allardt \& Starck, 1981; Bhopal, 1997). The Swedish-speakers may be considered a resource-strong minority in terms of linguistics, economics, and politics. It enjoys a relatively high level of ethnic organization (Allardt \& Starck, 1981), and it has even been regarded as a distinct nationality (Modeen, 1999).

Today, the Swedish-speaking community has a comprehensive network of educational institutions at all levels, a rich and versatile Swedish mass media supply, a great number of civil societies, commercial companies, and a political party of its own. Many Finland-Swedes in the Ostrobothnia region in Western Finland choose to follow Swedish affairs and cultural events as well as having Swedish media as a main source of information (Folktinget, 2006). Under the Language Act, the authorities shall protect the linguistic cultural tradition of the nation and promote the use of both national languages. In a bilingual municipality of Western Finland, Swedish can be selected as the first language of integration for immigrants, where studying and working in Swedish is offered as well (Ojala, 2020).

The Swedish-speaking minority in Ostrobothnia makes up approximately half of the population within the region, while the Swedish-speakers reach only 5,9\% of the total population of the country (Statistics Finland, 2020). Ostrobothnia appears as a region where the Swedish language and culture have a stronger position than in other areas of Swedish-speaking Finland, with the exception of the Åland Islands (Tarkiainen, 2008).

\subsection{Proactive Attitudes Towards Other Groups}

Proactive attitudes towards integration encompass efforts by both individuals and the state during the integration processes. Cultural efforts towards integration implicate changes in a majority's cultural attitudes towards the accommodation of the newcomers, including acceptance and promotion of a minority's cultural values, norms, and customs. Structural efforts implicate the willingness to change the society's institutional structures, including changes in law, public services, or making welfare distribution more egalitarian. Openness to diversity is a phenomenon that goes beyond non-prejudice and reflects an overall positive evaluation of cultural diversity (Phelps, Eilertsen, Türken, \& Ommundsen, 2011; Verkuyten 2007, 2009; Verkuyten \& Brug, 2004).

There is evidence demonstrating the value of experiences of diversity for a variety of positive outcomes, ranging from reducing racial bias to civic attitudes, behavioral intentions, and behaviors. It has been shown that within a university context, having an ethnically diverse student body is a necessary but not a sufficient condition for producing meaningful interactions. Interactions happening particularly outside the classroom bring positive changes in diversity experiences, at the same time as they prepare young adults to participate and flourish in a globalized and rapidly changing society (Bowman, 2011). Student engagement in diversity experiences is positively associated with experiencing the unexpected, which in 
turn is related to improved attitudinal outcomes. Thus, diversity experiences foster positive orientations toward equality and social responsibility (Bowman, 2012). This is in line with the so called "contact hypothesis" first proposed by Allport in his classical work "The nature of prejudice" (Allport, 1954) in which he stated that prejudice may be reduced by equal status contact between majority and minority groups in the pursuit of common goals.

Meta-analyses have corroborated the contact hypothesis and shown that, regardless of whether the interaction occurs across ethnic or across other forms of difference, intergroup contact, especially direct experiences of intergroup friendships, tend to reduce prejudice and improve attitudes towards other groups (Pettigrew \& Tropp, 2006; Tropp \& Pettigrew, 2005). Research has shown that intergroup contact reduces prejudice even when Allport's optimal contact conditions (equal status contact, and the pursuit of common goals) are not met (Tropp $\&$ Pettigrew, 2005). It has also been shown that the contact-effect is asymmetrical in the sense that it is stronger for majority members (Tropp \& Pettigrew, 2005).

The weight of evidence suggests that attendance of university is associated with a wide range of positive openness to diversity outcomes, and it also creates conditions for the students to develop greater tolerance (Pascarella \& Terenzini, 2005). To add on, structural efforts of an institution to emphasize and support multicultural diversity among faculty and students have been shown to have a positive impact on individual students' commitment to promote cultural and social understanding (Pascarella, Edison, Nora, Hagedorn, \& Terenzini, 1996).

In a university student sample, Barkley, Boone and Hollowat (2005) examined the determinants of openness to diversity, including experience with diversity, gender, size of hometown, enrolled credit hours, desire to obtain an advanced degree, outside work experience, and major field of study. Students from small cities were slightly more likely to be open to diversity than respondents raised in the countryside. Also, personality played an important role in shaping attitudes toward diversity. Undergraduate students who studied more than others and had a desire to seek an advanced degree were significantly more open to diversity than students who did not have a desire to further their education beyond the undergraduate level. Students who had a job, and students who lived with friends not enrolled in college, were less open to diversity. Overall, student involvement within an institution itself, engagement with peers of different backgrounds, and collaborative communication and learning had positive effects on openness to diversity. These results are quite consistent across studies, showing that the positive impact of attending university on students' openness to diversity over an extended period of time is a result of a set of interrelated experiences rather than a result of a single experience (Loes, Culver, \& Trolian, 2018; Pascarella \& Terenzini, 1991; Pacarella, Edison, Nora, Hagedorn, \& Terenzini, 1996; Pike, 2002).

\subsection{Purpose of the Study}

The purpose of the current study was to examine social integration and proactive attitudes towards integration in a sample of the Swedish-speaking minority of Western Finland. An addressed hypothesis was that the better members of the Swedish-speaking population experience themselves integrated in society, the more positive attitudes they will have towards the integration of immigrants. The measured proactive attitudes towards immigrants 


\section{Macrothink}

included the recognition of the need for making (a) cultural and (b) structural efforts in support of the integration of immigrants, and (c) openness to diversity. These factors are related to the respondents' self-reported level of social integration. The analysis of the current study was exploratory, since according to the knowledge of the authors, there are no published studies on the subject matter.

\section{Method}

\subsection{Sample}

A questionnaire was completed by 298 Swedish-speaking respondents in the region of Ostrobothnia in Western Finland, comprising of 208 females and 90 males. The mean age was 31.6 years $(S D=13.4)$. The age span was between 16 and 90 years.

\subsection{Instrument}

A questionnaire was constructed for the measurement of the level of social integration of the respondents, and the level of their proactive attitudes towards integration of immigrants. Social integration was measured with a scale consisting of 27 items. The Cronbach's alpha of this scale was .91. The items of the scale measure different aspects of how well the respondents experience themselves to be integrated in the surrounding society. The items measure access to social benefits (e.g., "I can easily access health care"), satisfaction with the neighbourhood (e.g., "Neighbours are hospitable and friendly"), positive social relations (e.g., "My rights, beliefs, and opinions are respected by others"), and trust in the Finnish judiciary system (e.g., "I have trust in the Finnish legal system"). For a complete list of the single items, see Grigaitytė, Österman, and Björkqvist (2020). All response alternatives were on a five-point scale $(0=$ disagree completely, $1=$ partly disagree, $2=$ neutral, $3=$ partly agree, 4 $=$ agree completely).

Proactive attitudes towards integration were measured with three subscales titled as cultural efforts, structural efforts, and openness to diversity. Respondents were asked to choose between response alternatives on a five-point scale $(0=$ strongly disagree to $4=$ strongly agree). The scale was originally developed by Phelps, Eilertsen, Türken, and Ommundsen (2011) and specifically adapted for this study (see also Grigaitytè, Österman, \& Björkqvist, 2019). A complete list of the items of the subscales, including the Cronbach's $\alpha$-values, is presented in Table 1. 


\section{Macrothink}

Table 1. Single Items and Cronbach's Alphas for the Scales Measuring Cultural Efforts, Structural Efforts, and Openness to Diversity $(N=298)$

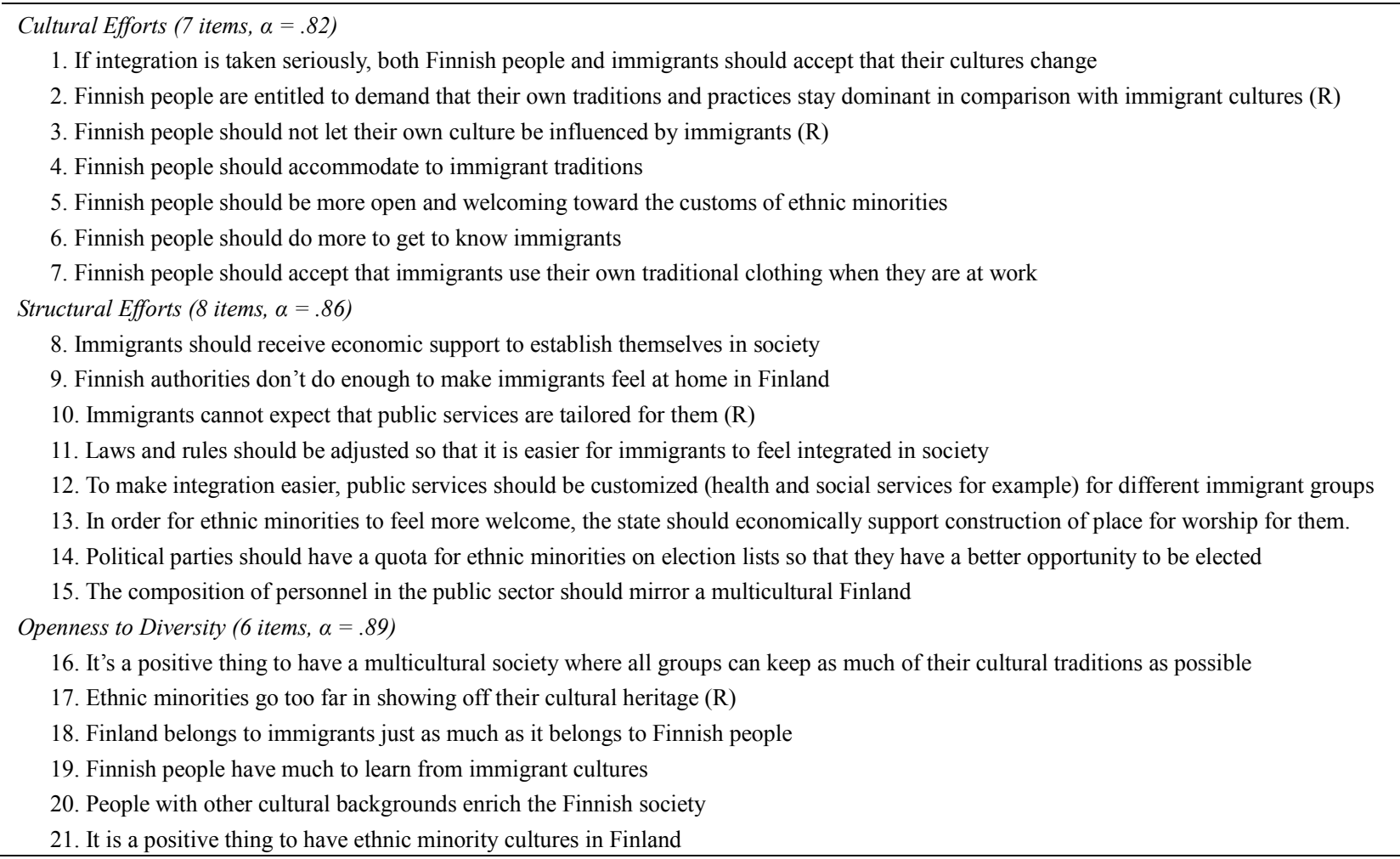
Note. $(\mathrm{R})=$ Recoded.

\subsection{Procedure}

A link to an online version of the questionnaire was placed on the main webpage of a city library. A paper-and-pencil version was also available, as well as a box where the questionnaires could be dropped anonymously. Furthermore, the link to the questionnaire was shared on social media as well as distributed to employees at a large workplace.

\subsection{Ethical Considerations}

All respondents taking part in the investigation were anonymous. The study follows the ethical principles regarding scientific research with humans stipulated in the Declaration of Helsinki (World Medical Association, 2008) as well as the guidelines for research by the Finnish Advisory Board on Research Integrity (2012). The handling and publication of data is done in accordance with the regulations of data protection by European Commission (2016).

\section{Results}

\subsection{Correlations Between the Scales}

Social integration corelated significantly positively with structural efforts to integrate immigrants $[r=.14, p=.016]$, and with scores on openness to diversity $[r=.20, p=.001]$. A tendency towards a significant correlation was found for the correlation with cultural efforts to integrate immigrants $[r=.12, p=.053]$. 


\subsection{Social Integration and Proactive Attitudes towards Integration of Immigrants}

The participants were divided into two groups based on their scores for how well they experienced themselves to be integrated in the society. The scores for social integration were transformed into $z$-scores, and participants with a mean $\leq$ zero were assigned to the low social integration group, while those having a mean score above zero were assigned to the high social integration group. A multivariate analysis of variance (MANOVA) was conducted with social integration group (high/low) as independent variable and three types of proactive attitudes towards integration of immigrants as independent variables. The results are presented in Table 1 and Figure 1. The multivariate analysis was significant for social integration group. The univariate analyses showed that respondents who belonged to the group with high scores on social integration scored significantly higher on cultural efforts, structural efforts, and openness to diversity than those with lower scores on social integration. The most prominent difference between the groups was in the case of openness to diversity.

Table 2. Results of a Multivariate Analysis of Variance (MANOVA) with Social Integration Group (High/Low) as Independent Variable and Three Types of Proactive Attitudes towards Integration of Immigrants as Dependent Variables $(N=298)$

\begin{tabular}{lcccc}
\hline \multicolumn{1}{l}{$F$} & $d f$ & $p$ & $\eta_{p}{ }^{2}$ \\
\hline Effect of Social Integration Group (High/Low) & & & \\
Multivariate Analysis & 4.10 & 3,294 & .007 & .040 \\
Univariate Analyses & & & & \\
Cultural Efforts & 4.71 & 1,296 & .031 & .016 \\
Structural Efforts & 5.57 & “ & .019 & .018 \\
Openness to Diversity & 10.94 & “ & .001 & .136 \\
\hline
\end{tabular}




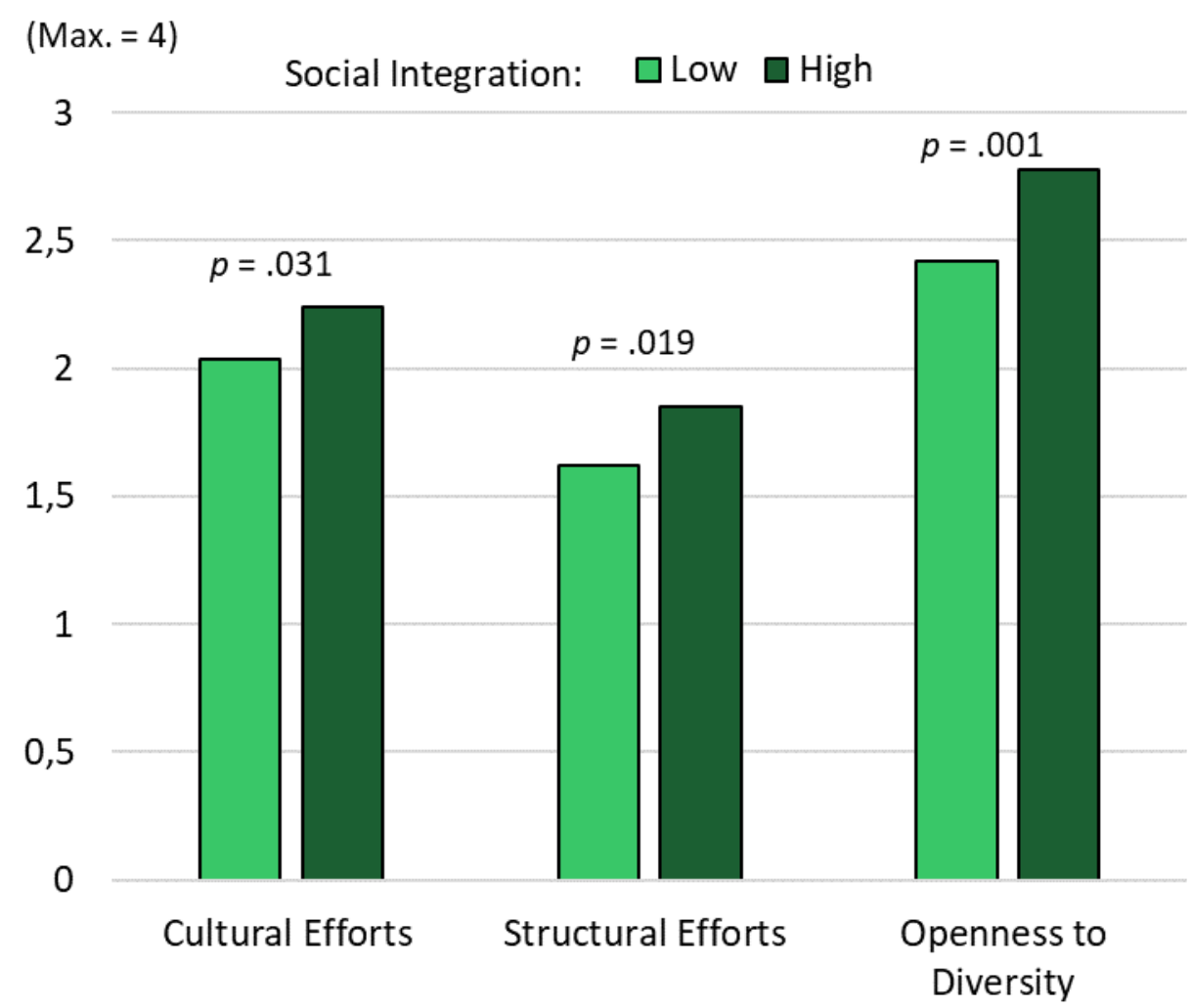

Figure 1. Mean values for three types of proactive attitudes towards integration of immigrants for respondents scoring either high or low on their personal level of social integration $(N$ $=298)$

\section{Discussion}

A limitation of the study is that the sample cannot be claimed to be fully representative. However, since the research question concerned the relationship between variables (one's personal level of social integration in relation to proactive attitudes towards immigration) rather than the comparison between groups, this circumstance should not render the findings questionable. The results showed that the respondents (who all were Swedish-speakers from Western Finland) who were well socially integrated had more positive attitudes towards the integration of immigrants than those who were less well integrated. This finding suggests that being well-integrated is enhancing positive attitudes towards immigrants, but the mechanism behind this circumstance is unclear. Perhaps well-integrated individuals feel their existence less threatened by the newcomers, and they are therefore better able to experience immigrants and cultural diversity as a resource.

The Swedish-speaking minority of Finland is as a whole regarded as relatively well-integrated in the Finnish society. The Finland-Swedes has been residing in the country for approximately nine centuries, and their language, culture, and education are protected by the Finnish constitution (Allardt \& Starck, 1981). It has been found that Swedish-speakers, in comparison with Finnish-speakers, have more positive attitudes towards immigrants 
(Pitkänen \& Westinen, 2018), The fact that they are so supportive towards the integration of immigrants contradicts previous research suggesting that minorities are more likely than a majority group to reject other minorities, in order to draw attention to their own ethnic existence (Hindriks, Coenders, \& Verkuyten, 2005). Due to the fact that Swedish-speakers are a well-integrated minority group, they may not experience new minorities as a threat to their existence; instead, they seem to empathize with the incoming minority groups in the country. Belonging to a minority group themselves, they might better understand the difficulties of being a minority.

The scale measuring proactive attitudes consisted of three subscales. The subscale measuring cultural efforts focused on required changes in the majority's cultural attitudes in order to facilitate the accommodation of the newcomers. It also included acceptance of values and customs of the immigrant groups. The subscale measuring structural efforts included efforts required of the institutions and the state itself. It focused on required changes in law and public services to support and accommodate immigrants. The subscale measuring openness to diversity focused on the evaluation of cultural diversity in Finland. More precisely, it taggled an opinion whether Finland belongs to immigrants as much as to Finnish people (Grigaitytè, Österman, \& Björkqvist, 2019; Phelps, Eilertsen, Türken, \& Ommundsen, 2011).

Research among university students demonstrate that experiencing diversity improves attitudes towards differences among people in terms of behaviors and cultural habits and helps to decrease prejudice and racial bias (Bowman, 2011; Pettigrew \& Tropp, 2006; Tropp $\&$ Pettigrew, 2005). This phenomenon has been called the intergroup contact theory (Allport, 1954). In order to produce meaningful interactions between minorities and the majority group, both cultural and structural efforts are required.

Cultural and structural efforts create conditions for the development of greater openness to diversity, and also for overall engagement with individuals of different backgrounds; collaborative communication and doing things together have positive effects. It is essential to keep in mind that integration is a result of multiple interrelated experiences rather than of a single experience that set the basis for overall proactive attitudes towards integration. Thus, it is a continuous process of experiences happening over an extended period of time that shapes the attitudes of an individual.

\section{Conclusion}

Social integration is a multifaceted, two-way, long-term, and open-process experience for both local and immigrant populations. As Finland is moving from a relatively homogenous to more ethnically diverse country, having a more comprehensive understanding on current social integration demeanors and practices may enhance the general social, structural, and cultural health of the society.

Throughout the centuries, the Swedish-speaking minority has achieved a solid position within the Finnish society, having a wide-ranging network of educational, commercial, and political institutions. The high levels of social integration contribute to more open attitudes towards the more recently immigrated ethnic groups. As this study has demonstrated, the better 
individuals are socially integrated into their own community, the more positive attitudes they tend to have towards the integration of immigrants.

During the integration processes, proactive attitudes towards integration should encompass efforts by both individuals and the state in order to maintain positive social relationships within the community. The findings of this study could have valuable implications for the policy makers and policy implementers to construct instruments for diverse integration services.

Future studies are recommended to replicate the current study with an adoptive scale measuring cultural efforts, structural efforts, and openness to diversity for the measurement of social integration both among local and immigrant populations. It may include various cultural, religious, and linguistic groups residing not only in Western Finland but also in the rest of a country, Nordic countries and elsewhere in the world. First, it would be beneficial to see how the immigrants themselves view their proactive attitudes towards their social integration. Second, it would be valuable to compare immigrant attitudes to the attitudes of the local populations. Also, exploratory qualitative research (Silverman, 2016) may provide a more detailed picture about the dynamics of social integration and individuals' attitudes on proactive attitudes connected to own social integration.

\section{References}

Ager, A., \& Strang, A. (2008). Understanding integration: A conceptual framework. Journal of Refugee Studies, 21, 166-191. https://doi.org/10.1093/jrs/fen016

Allardt, E., \& Starck, C. (1981). Språkgränser och samhällsstruktur: Finlandssvenskarna i ett jämförande perspektiv. Lund, Sweden: Almqvist \& Wiksell.

Allport, G. W. (1954). The nature of prejudice. Cambridge, MA: Perseus Books

Andersson, H., \& Herberts, K. (1996). The case of the Swedish-speaking Finns. International Review of Education, 42, 384-388. https://doi.org/10.1007/BF00601099

Barkley, A. P., Boone, K., \& Hollowat, Z. W. (2005, July). Openness to diversity and challenge: Assessment of undergraduate attitudes and experiences in the College of Agriculture at Kansas State University. Paper presented at American Agricultural Economics Association (AAEA) annual meeting, Providence, USA.

Berry, J. W. (2011). Integration and multiculturalism: Ways towards social solidarity. Papers on Social Representations, 20, 1-21.

Bhopal, R. (1997). Is research into ethnicity and health racist, unsound, or important science? British Medical Journal, 314, 1751-1756. https://doi.org/10.1136/bmj.314.7096.1751

Black, S. (2006). Cosmopolitanism at home: Amitav Ghosh's shadow lines. Journal of Commonwealth Literature, 41, 45-65. https://doi.org/10.1177/0021989406068734

Brissette, I., Cohen, S., \& Seeman, T. E. (2000). Measuring social integration and social networks. In S. Cohen, L. G. Underwood \& B. H. Gottlieb (Eds.), Social support 
measurement and intervention: A guide for health and social scientists (pp. 53-85). Oxford, UK: Oxford University. https://doi.org/10.1093/med:psych/9780195126709.003.0003

Bowman, N. A. (2011). Promoting participation in a diverse democracy: A meta-analysis of college diversity experiences and civic engagement. Review of Educational Research, 81, 29-68. https://doi.org/10.3102/0034654310383047

Bowman, N. A., \& Brandenberger, J. W. (2012). Experiencing the unexpected: Toward a model of college diversity experiences and attitude change. The Review of Higher Education, 35, 179-205. https://doi.org/10.1353/rhe.2012.0016

Department of Economic and Social Affairs (UNDESA) Division for Social Policy and Development, New York. Retrieved from https://www.un.org/development/desa/family/wp-content/uploads/sites/23/2018/05/Robila_E GM_2018.pdfEngman, M. (1995). Finns and Swedes in Finland. In S. Tägil (Ed.), Ethnicity and nation building in the nordic world (pp. 179-216). London, UK: Hurst.

Esser, H. (1980). Aspekte der Wanderungssoziologie. Assimilation und Integration von Wanderern, ethnischen Gruppen und Minderheiten. Darmstadt, Neuwied: Luchterhand.

Esser, H. (2006). Sprache und Integration. Die sozialen Bedingungen und Folgen des Spracherwerbs von Migranten. Frankfurt, New York: Campus.

Folktinget. (2006). Identitet och framtid. Folktingets undersökning om finlandssvenskarnas identitet hösten 2005. Vasa, Finland: Fram.

Haggren, G., Halinen, P., Lavento, M., Raninen, S., \& Wessman, A. (2015). Muinaisuutemme jäljet: Suomen esi-ja varhaishistoria kivikaudelta keskiajalle. Helsinki, Finland: Gaudeamus.

Hindriks, P., Coenders, M., \& Verkuyten, M. (2005). Interethnic attitudes among minority groups: The role of identity, contact, and multiculturalism. In Majorities' attitudes towards minorities: Key findings from the Eurobarometer and the European Social Survey. Retrieved from https://fra.europa.eu/sites/default/files/fra_uploads/146-EB2005-summary.pdf

Holm, K., Nokelainen, P., \& Tirri, K. (2009). Relationship of gender and academic achievement to Finnish students' intercultural sensitivity. High Ability Studies, 20, 187-200. https://doi.org/10.1080/13598130903358543

Høy-Petersen, N., Woodward, I., \& Skrbis, Z. (2016). Gender performance and cosmopolitan practice: Exploring gendered frames of openness and hospitality. Sociological Review, 64, 970-986. https://doi.org/10.1111/1467-954X.12390

Integration. (2020). Supporting work. $\quad$ Retrieved from https://kotouttaminen.fi/en/supporting-work

Kuusisto, A., Kuusisto, E., Holm, K., \& Tirri, K. (2014). Gender variance in interreligious sensitivity among Finnish pupils. International Journal of Children's Spirituality, 19, 25-44. https://doi.org/10.1080/1364436X.2014.887560

Loes, C. N., Culver, K. C., \& Trolian, T. L. (2018). How collaborative learning enhances 
students' openness to diversity. Journal of Higher Education, 89, 935-960. https://doi.org/10.1080/00221546.2018.1442638

McRae, K. D., Helander, M., \& Luoma, S. (1999). Conflict and compromise in multilingual societies: Finland (vol. 306). Waterloo, Ontario, Canada: Wilfrid Laurier Univ. Press.

Ministry of Economic Affairs and Employment of Finland. (2016). Government integration programme for 2016-2019 and government resolution on a government integration programme. Helsinki, Finland: Ministry of Economic Affairs and Employment. Retrieved from http://julkaisut.valtioneuvosto.fi/bitstream/handle/10024/79156/TEMjul_47_2016_verkko.pd $\mathrm{f}$

Modeen, T. (1999). The cultural rights of the Swedish ethnic group in Finland. Europa Ethnica, 56, 135-145.

OECD. (2018). Migration in Finland and the context of integration policy. In OECD (Ed.), Working together: skills and labour market integration of immigrants and their children in Finland (pp. 45-67). Paris, France: OECD Publishing. https://doi.org/10.1787/9789264305250-5-en

Ojala, M. (2020). Ostrobothnia, Central Ostrobothnia and South Ostrobothnia. Retrieved from https://kotouttaminen.fi/en/ostrobothnia-and-south-ostrobothnia

Pascarella, E. T., Edison, M., Nora, A., Hagedorn, L. S., \& Terenzini, P. T. (1996). Influences on students' openness to diversity and challenge in the first year of college. Journal of Higher Education, 67, 174-195. https://doi.org/10.2307/2943979

Pascarella, E. T., \& Terenzini, P. T. (2005). How college affects students: A third decade of research (vol. 2). Indianapolis, IN: Jossey-Bass.

Pettigrew, T. F., \& Tropp, L. R. (2006). A meta - analytical test of the intergroup contact theory. Journal of Personality and Social Psychology, 90, 751-783. https://doi.org/10.1037/0022-3514.90.5.751

Phelps, J. M., Eilertsen, D. E., Türken, S., \& Ommundsen, R. (2011). Integrating immigrant minorities: Developing a scale to measure majority members' attitudes toward their own proactive efforts. Scandinavian Journal of Psychology, 52, 404-410. https://doi.org/10.1111/j.1467-9450.2011.00876.x

Pike, G. R. (2002). The differential effects of on-and off-campus living arrangements on students' openness to diversity. NASPA Journal, 39, 283-299. https://doi.org/10.2202/0027-6014.1179

Pitkänen, V., \& Westinen, J. (2018). Identiteter på två språk. En undersökning om svenskspråkiga och finskspråkiga. e2 \& Kulttuurirahasto, Report 3. Helsinki, Finland: Kirjapaino Öhrling.

Ratts, M. J., \& Pedersen, P. B. (2014). Counseling for multiculturalism and social justice: 
Integration, theory, and application. Alexandria, VA: John Wiley.

Robila, M. (Ed.). (2018). Refugees and social integration in Europe. United Nations

Sarvimäki (2017). Labor market integration of refugees in Finland. VATT Research Reports, 185. https://doi.org/10.2139/ssrn.2921095

Saxén, R. (1905). Språkliga bidrag till den svenska bosättningens historia i Finland. 1. Egentliga Finland, Satakunta och södra Österbotten. Helsingfors, Finland: Finska Litteratursällskapet.

Silverman, D. (Ed.). (2016). Qualitative research. London, UK: Sage.

Strang, A., \& Ager, A. (2010). Refugee integration: Emerging trends and remaining agendas. Journal of Refugee Studies, 23, 589-607. https://doi.org/10.1093/jrs/feq046

Tapaninen, A. M., Halme-Tuomisaari, M., \& Kankaanpää, V. (2019). Mobile lives, immutable facts: Family reunification of children in Finland. Journal of Ethnic and Migration Studies, 45, 825-841. https://doi.org/10.1080/1369183X.2017.1405725

Tarkiainen, K. (2008). Sveriges österland: Från forntiden till Gustav Vasa. Finlands svenska historia (vol. 1). Helsingfors \& Stockholm: Svenska Litteratursällskapet i Finland.

Tropp, L. R., \& Pettigrew, T. F. (2005). Relationships between intergroup contact and prejudice among minority and majority status groups. Psychological Science, 16, 951-957. https://doi.org/10.1111/j.1467-9280.2005.01643.x

Umberson, D., \& Karas, M. J. (2010). Social relationships and health: A flashpoint for health policy. Journal of Health and Social Behavior, 51(1_suppl), S54-S66. https://doi.org/10.1177/0022146510383501

Valtioneuvosto (2015). Finland a land of solutions. Strategic programme of a Finnish government. $\quad$ Retrieved from https://valtioneuvosto.fi/documents/10184/1427398/Hallitusohjelma_27052015_final_EN.pdf /f1071 fae-a933-4871-bb38-97bdfd324ee6

Verkuyten, M. (2007). Social psychology and multiculturalism. Social and Personality Psychology Compass, 1, 280-297. https://doi.org/10.1111/j.1751-9004.2007.00011.x

Verkuyten, M. (2009). Support for multiculturalism and minority rights: The role of national identification and out- group threat. Social Justice Research,22, 31-52. https://doi.org/10.1007/s11211-008-0087-7

Verkuyten, M., \& Brug, P. (2004). Multiculturalism and group status: The role of ethnic identification, group essentialism and protestant ethic. European Journal of Social Psychology, 34, 647-661. https://doi.org/10.1002/ejsp.222 


\section{Copyrights}

Copyright for this article is retained by the author(s), with first publication rights granted to the journal.

This is an open-access article distributed under the terms and conditions of the Creative Commons Attribution license (http://creativecommons.org/licenses/by/4.0/). 